\title{
THE IMPACT OF RECRUITMENT, EMPLOYEE RETENTION AND LABOR RELATIONS TO EMPLOYEE PERFORMANCE ON BATIK INDUSTRY IN SOLO CITY, INDONESIA
}

\author{
Eddy Madiono Sutanto* \\ Petra Christian University \\ Milly Kurniawan \\ Petra Christian University
}

\begin{abstract}
The good recruitment program can provide a positive influence to increasing employee commitment, productivity and the quality of work including performance. The relationship of employee retention on performance is exceedingly complex. There is evidence that performance can decrease if the employee retention is bad and there is a possibility of stagnation if employee turnover is too dejected. Besides recruitment and employee retention, the labor relations can also affect the employee performance, where the problems usually arise from the difference of work, age and demographics. Research will be conducted to examine, whether there is a significant impact on recruitment, employee retention, and labor relations to employee performance on batik industry in Solo. The results of this analysis indicate that the recruitment, retention, and labor relations found a significant effect on employee performance. On the other hand, the recruitment and employee retention found a significant effect on employee performance. As well as recruitment and employee retention, labor relations found significant effects to the employee retention. The results also found the recruiting and employee retention have a significant impact on employee performance through the labor relations. As well as the recruitment significantly influence on labor relations through the employee retention.
\end{abstract}

Keywords: Recruitment; Employee Retention; Labor Relations; Employee Performance.

\section{INTRODUCTION}

On previously research by Rafii and Andri (2015) concerning the recruitment that there is a relationship between the recruitment with employee performance. Research uncovers the existence of a positive and significant relationship between recruitment and employee performance. Other studies have stated that a good recruitment program can provide a positive influence towards increasing employee commitment, productivity, the work quality and performance (Patimah, 2015). Based on the results of previous studies, retention was also positive directly influenced on employee performance, indicated that

\footnotetext{
*Corresponding author: Eddy Madiono Sutanto, School of Business Management, Petra Christian University, 60236, Surabaya, East Java, Indonesia. Tel: +62818391691. Email: esutanto@petra.ac.id
} 
the retention of good employee will result in improved employee performance (Susilo, 2013). According to Glebbek and Back, the relationship between employee retention on performance is exceedingly complex. There is evidence that performance can fall if the bad employee retention and there is a possibility of employee stagnation if the turnover is too depressed (Sumarni, 2011). A bad employee retention program will improve the employee's intention to move or turnover intention, if an employee gets what they want, then it will improve performance (Sumarni, 2011).

Labor relations also have relationship to employee performance. According to Amjad (in Situngkir, 2013) labor relations can affect the operation of the employee where the problems normally arise from the difference of work, age and demographics. According to Jacqueline et al., it was proved by the research which concluded that the relationship between teams or workgroup has a positive influence on employee performance (in Situngkir, 2013). Established along the phenomenon and the discussion of the background of the above problems, the research will be conducted to examine whether there is a significant impact on the recruitment, employee retention, and labor relations to employee performance on batik industry in Solo.

\section{LITERATURE REVIEW}

\subsection{Recruitment and Employee Retention}

Recruitment is effected on most of the employee retention. The fair recruitment significantly affects employee retention (Janjua and Gulzar, 2014). Proved research conducted by Bernardin and Russell which states that employee recruitment practices and policies affecting employee retention (in Maina, 2014). The average recruitment of employees in an organization have the same recruitment system, differing only relates to the process, decision-making responsibility in recruitment, employment package, and whether public or private recruitment agencies (Maina, 2014). Boselie, Dietz and Boon said that recruitment and retention is most influenced by the overall employment package (in Maina, 2014). This includes salaries and allowances, the intrinsic aspects of the job (e.g. for academic, teaching and research), job security, work organization, autonomy, the development of family-friendly practices, work environment, etc. According to Pirzada et al., The increasingly attractive employment package, the more likely it will attract candidates or applicants and the greater employee retention (in Maina, 2014). Based on previous research, then the first hypotheses:

$H_{1}$ : There is a significant impact on recruitment with employee retention on batik industry in Solo.

\subsection{Recruitment and Labor Relations}

There is a relationship between recruitment and labor relations. Recruitment can be badly affected labor relations within the organization. Recruitment requires time and the costs are expensive enough, and then the decisions made must be appropriate. A new employee who does not comply with the organizational goals and ethos can damage a 
labor relations (Tunggal and Setiawan, 2015). It harms and hinders the efforts to help the cooperation formation within the group. Based on previous research, then the second hypotheses:

$\mathrm{H}_{2}$ : There are significant impact labor relations with employee recruitment on batik industry in Solo.

\subsection{Employee Retention and Labor Relations}

On the previously research stated that there are relationships between employee retention with labor relations. A bad employee retention will increase employee turnover. For an employee, a high turnover rate will affect employee morale, labor relations and job security or badly working relationships within the organization (Sumarni, 2011). Based on previous research, then the third hypotheses:

$H_{3}$ : There is a significant impact employee retention with labor relations on batik industry in Solo.

\subsection{Recruitment and Employee Performance}

Recruitment is also one of the factors that can affect the employee performance and reinforced with the opinion from Castetter (in Pambagio et al., 2013), which suggests that the implementation of recruitment which are not in accordance with the plan that has been set, will cause problems such as low performance, high levels of employee absenteeism, often too late, and others. With a good recruitment, it will pull in more qualified employee so the performance will also be safer. The good recruitment program will be able to give positive influence to increase employee commitment, productivity and the work quality (Patimah, 2015). Based on previous research, then the fourth hypotheses:

$H_{4}$ : There is a significant impact on recruitment with employee performance on batik industry in Solo.

\subsection{Employee Retention and Employee Performance}

The relationship between employee retention and employee performance is known from previous research. There is a direct positive influence employee retention on employee performance (Susilo, 2013). This means that the higher employee retention will increase the employee performance. According to Mangkunegara, the performance is a result of someone's effort and achieved by the presence of a person's ability and the act in certain situations (in Sumarni, 2011). This particular situation can be intervened and created by the company, namely through a strategic employee retention program that is appropriate and sustainable. Based on previous research, then the fifth hypotheses:

$H_{5}$ : there is significant impact employee retention with the employee's performance on batik industry in Solo. 


\subsection{Labor Relations and Employee Performance}

Ernawati and Ambarini (2010) said that the labor relations had a significant influence on employee performance. According to Amjad (in Situngkir, 2013), relations between employee can affect the employee performance where the problems usually arise from the difference of work, age and demographics. It gives rise to differences of opinion and culminate in a conflict that could affect the employee performance. This is apparent from the research Jacqueline et al. (in Situngkir, 2013), which concluded that the relationship created within the team or group have positive effect on employee performance. Emmanuel (in Situngkir, 2013) deduced that a good communication entwined in the working relationship will impact the employee performance, where there is no need to spend time to argue over arguments. Based on previous research, then the sixth hypotheses:

$H_{6}$ : there are significant impact labor relations with employee performance on batik industry in Solo.

\subsection{Recruitment, Employee Retention and Labor Relations}

Recruitment of employee affect most employee retention. The fair recruitment significantly affect employee retention (Janjua and Gulzar, 2014). Proved research conducted by Bernardin and Russell which states that employee recruitment practices and policies affecting employee retention (in Maina, 2014). The average recruitment of employees in an organization have the same recruitment system, differing only relates to the process, decision-making responsibility in recruitment, employment package, and whether public or private recruitment agencies (Maina, 2014), on the other hand a bad employee retention will increase employee turnover. A high turnover rate will affect employee morale, employee relations and job security or badly labor relations within the organization (Sumarni, 2011). Based on previous research, then the seventh hypotheses:

$H_{7}$ : there is a significant impact on the recruitment with labor relations on the batik industry in Solo through the employee retention.

\subsection{Recruitment, Labor Relations and Employee Performance}

There is a relationship between recruitment and labor relations. Recruitment can be badly labor relations within the organization. Recruitment takes time and costs were quite expensive, and so the decisions made must be appropriate. A new employee who does not comply with the organizational goals and ethos can damage a labor relations (Tunggal and Setiawan, 2015), on the other hand the relationship between employees can affect the performance of the employee where the problems usually arise from the difference of work, age and demographics. It gives rise to differences of opinion and culminate in a conflict that could affect the employee performance. This is apparent from the research Jacqueline et al. (in Situngkir, 2013), which deduced that the relationship within the team have a positive effect against the employee performance. Based on previous research, then the eight hypotheses: 
$H_{8}$ : there is a significant impact on recruitment with the employee's performance batik industry in Solo through the labor relations.

\subsection{Employee Retention, Labor Relations and Employee Performance}

On the previously research stated that there are relationships between the employee retention with labor relations. A bad employee retention will increase employee turnover. For employee, a high turnover rate will affect employee morale, employee relations and job security or badly labor relations within the organization (Sumarni, 2011), on the other hand the relationship between employees can affect the employee performance where the problems usually arise from the difference of work, age and demographics. It gives rise to differences of opinion and culminate in a conflict that could affect the performance of the employee. This is evident from the research Jacqueline et al. (in Situngkir, 2013), which concluded that the relationship within the team have a positive effect against the employee performance. Based on previous research, then the ninth hypotheses:

$H_{9}$ : there is significant impact employee retention with employee performance on batik industry in Solo through the labor relations.

Figures 1: Research Framework

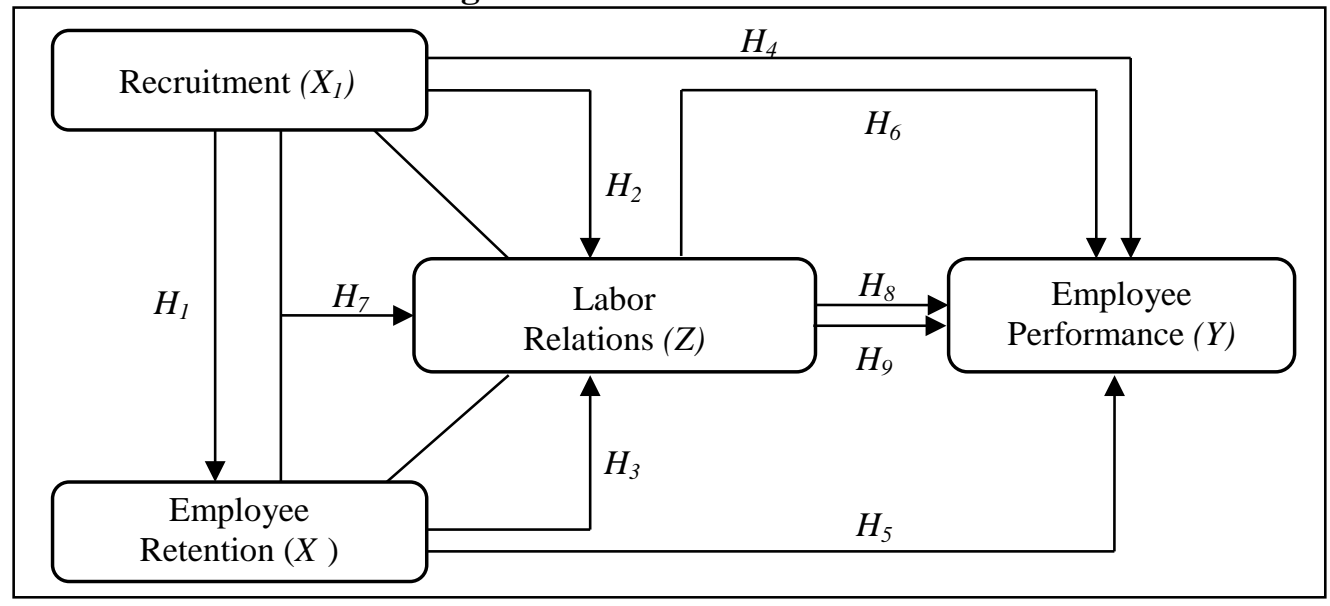

\section{RESEARCH METHODS}

Type of research practiced in this research is a quantitative research with explanative method. The reason the use of the explanative method to identify and examine relationships between variables that can make generalizations that clarify the description near the object of inquiry. Independent variables in this study are recruitment (X1) and employee retention (X2), and then the intervening variables in this study is the labor relations $(\mathrm{Z})$ and the employee performance $(\mathrm{Y})$ as the dependent variable. The research framework is shown in Figure 1. This research will use a research object, namely recruitment, 
employee retention, labor relations, and employee performance. Research subjects in this study were employee in the production of batik industry in Solo, Central Java.

The population in this research is the production employee in the batik industry in Solo as many as 715 people. The sample according to Noor (in Kristanto, 2015) as taking elements of the population, to taste that can represent the nature and characteristics of the population. The samples of this research uses techniques of nonprobability sampling that is purposive sampling in determining respondents, so that the data obtained in accordance with the needs of the research. The sample is determined using the formula slovin with error 5\% amounting to 375 from each company, 172 and 203 people from a total population of 715 employee's from the production division of the two textile companies in batik Solo.

Recruitment is a recruitment process compliance level applied by the company. Adopted from some research done by Gomes (2003, p. 111-114), Werner et al. (2012, p. 173) and Moekijat (in Sunyoto, 2012, p. 101-104). Maintenance employee or employee retention is the company's ability to sustain the potential employee owned company to remain loyal to the company. Linked from the definition regarding the employee retention, then the determined indicators for employee retention is variable from Sumarni (2011). Labor relations in the narrow sense is the interaction between a person with another person in a situation of employment and in the broad sense is the inter-action between a person with others heading to a work situation that motivated them to cooperate productively with feeling satisfied, both economic, social psychology and in achieving the objectives of the organization. The first labor relations indicators according to according to Situngkir (2013) is the level of conflict between the employee and the second indicator according to Matalia (2012) is the quality of communication between employyees. Employee performance is the outcome or the success rate of a person or during a certain period in carrying out its task and compared to the possibilities, such as the standard of work, target or targets have been fixed and mutually agreed earlier. Employee performance indicators using research Rivai and Basri (2005, p.14).

\section{DATA ANALYSIS}

\subsection{Test Validity and Reliability}

Test the validity of the model is based on the measuring or outer model that uses two convergent i.e. validity test of the values of the correlation is said to be valid if the value of the outer loading $>0.50$ and discriminant validity and using the value of cross loading (Ghozali, 2014, p. 39). Test values measured using composite reliability and Cronbach alpha (Ghozali, 2014, p. 65). Following the results of testing the validity of each indicator variable in research as shown in Table 1. 
Table 1: Validity Test

\begin{tabular}{ccccc}
\hline \hline & Recruitment & Employee Retention & Labor relations & Employee Performance \\
\hline R1 & 0.865016 & & & \\
R2 & 0.888268 & & & \\
R3 & 0.801815 & & & \\
R4 & 0.773149 & & & \\
RK1 & & 0.797025 & & \\
RK2 & 0.858004 & & \\
RK3 & 0.856871 & 0.824851 & \\
HK1 & & 0.793534 & \\
HK2 & & 0.900254 & \\
HK3 & & 0.852934 & \\
HK4 & & & 0.906316 \\
KK1 & & & 0.916621 \\
KK2 & & & \\
\hline \hline
\end{tabular}

The validity of the test results showed that all the indicators of each study variable has a value of outer loading $>0.50$ meaning may be said to be valid. In addition to using the value of the outer loading, validity test on Smart PLS, can also be done by looking at the value of the AVE on Table 2.

Table 2: Values AVE and Reliability Test

\begin{tabular}{cccc}
\hline \hline & AVE & Composite Reliability & Cronbach Alpha \\
\hline Recruitment & 0.694485 & 0.900640 & 0.852156 \\
Employee Retention & 0.701882 & 0.875853 & 0.786809 \\
Labor Relations & 0.712007 & 0.907986 & 0.864447 \\
Employee Performance & 0.830801 & 0.907579 & 0.796493 \\
\hline \hline
\end{tabular}

According to the table above it can be seen that the AVE value of every variable in this research is more than 0.50 so it can be said to be valid. Test results show the value of Cronbach alpha and composite reliability also had value more than 0.70 for every variable in this research, so it can be inferred that all the indicators of invalid constructs reflexive meets the test of reliability.

\subsection{Partial Least Square Analysis}

In the partial least square analysis (PLS) is used SmartPLS 3.0 program. Here is a picture of PLS models as shown in Figure 2 and Figure 3: 
Figure 2: Outer Model

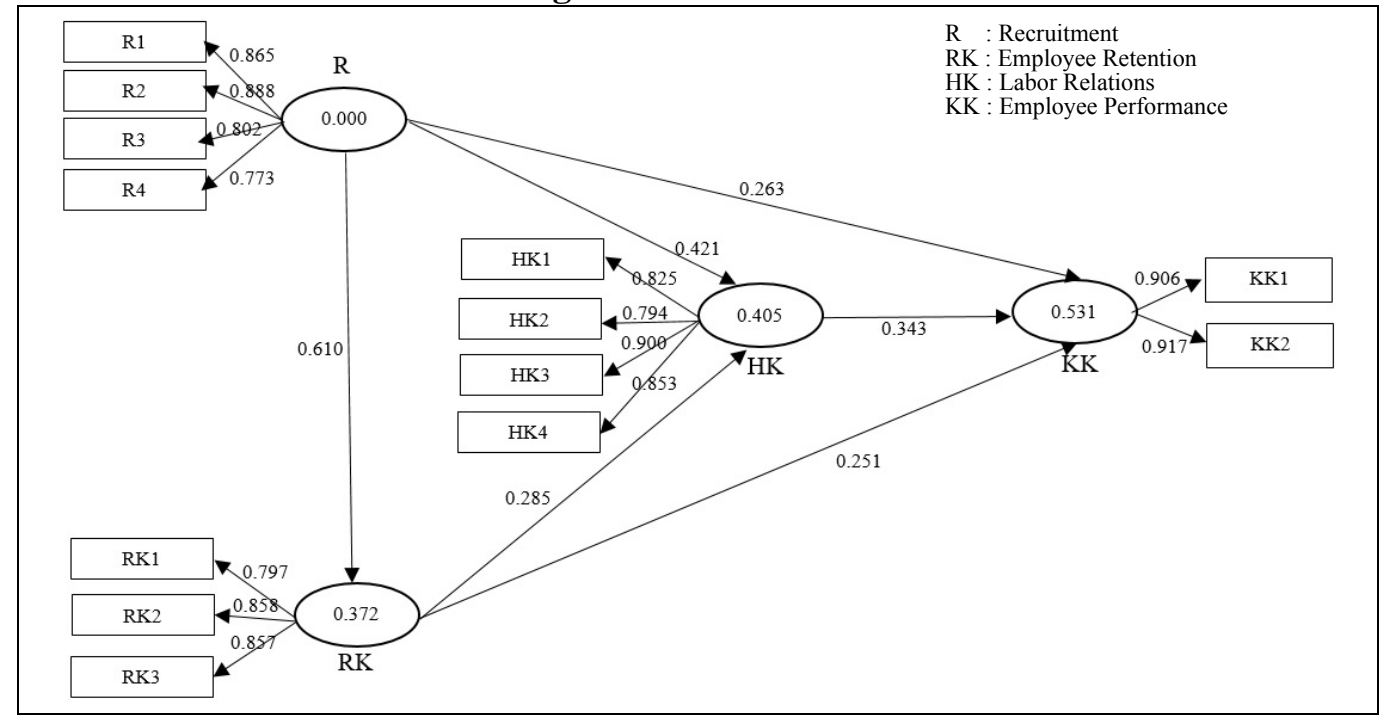

Figure 3: Inner Model

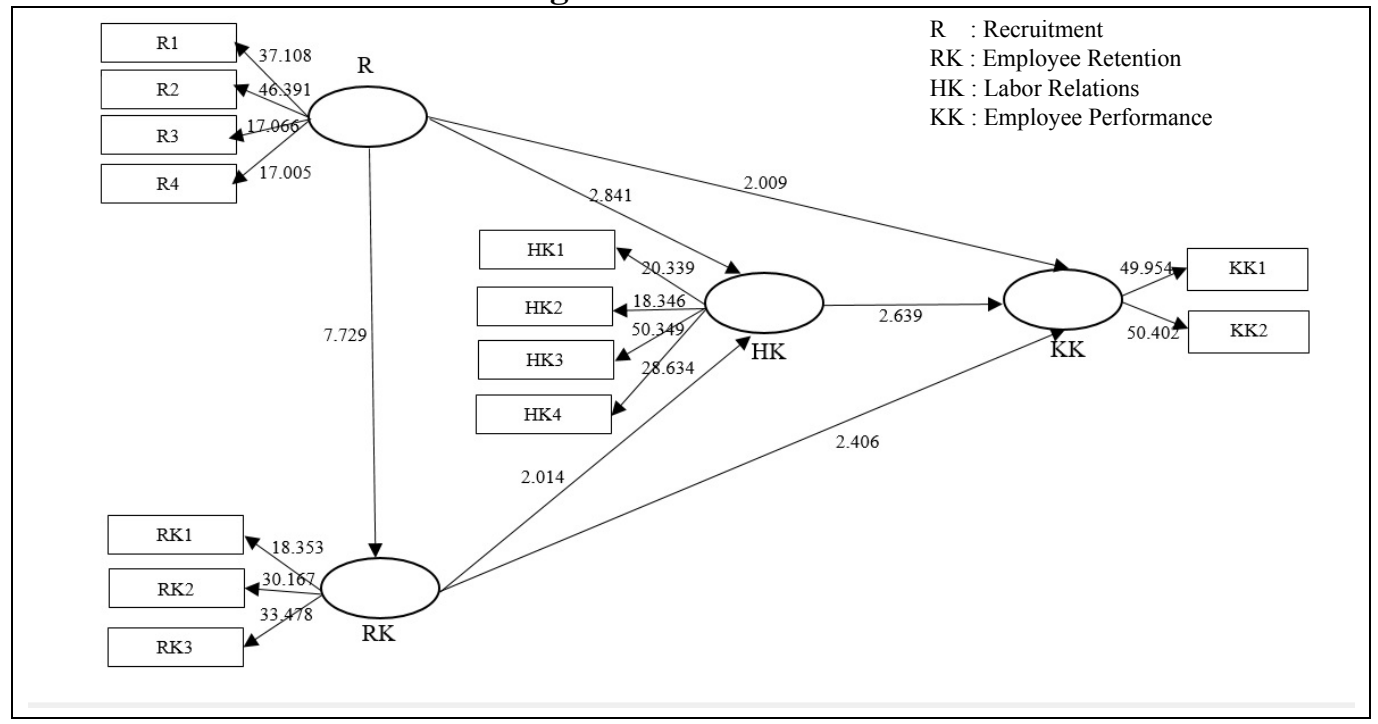

Based on the data processing by using PLS 3.0 has resulted the value of R-Square as shown in Table 3. 
Table 3: R-Square value

\begin{tabular}{cc}
\hline \hline Variable & R-Square \\
\hline Recruitment & - \\
Employee Retention & 0.372406 \\
Labor Relations & 0.404885 \\
Employee Performance & 0.531142 \\
\hline \hline
\end{tabular}

The value of R-Square for employee retention is at 0.3724 which means that a percentage the amount of employee retention can be explained by the recruitment amounted to $37.24 \%$ and the remaining $62.76 \%$ is explained by other factors outside the model. Value of R-Square for the labor relations is at 0.4049 which means a percentage the amount of labor relations can be explained by the retention and recruitment of employees amounted to $40.49 \%$ and the remaining $59.51 \%$ is explained by other factors outside the model. Last, for the performance of employees at 0.5311 means that the percentage the amount of employee performance can be explained by labor relations, employee retention and recruitment amounted to $53.11 \%$. The remaining $46.89 \%$ is explained by other factors outside the model.

With the test's path, the research hypothesis is acceptable if the value of the T-statistic $>1.96$. Here is the original sample estimate and the value of the T-statistic on the inner workings of the model as shown in Table 4.

Table 4: Impact Coefficient and T-statistics

\begin{tabular}{clccc}
\hline \hline Hypotheses & \multicolumn{1}{c}{ Relationships } & Coefficient & T-statistic & Description \\
\hline & Direct Relationship & & & \\
$H_{1}$ & Recruitment $\rightarrow$ Employee Retention & 0.610251 & 7.729252 & Accepted \\
$H_{2}$ & Recruitment $\rightarrow$ Labor Relations & 0.420733 & 2.841023 & Accepted \\
$H_{3}$ & Employee Retention $\rightarrow$ Labor Relations & 0.285272 & 2.014089 & Accepted \\
$H_{4}$ & Recruitment $\rightarrow$ Employee Performance & 0.263208 & 2.009418 & Accepted \\
$H_{5}$ & Employee Retention $\rightarrow$ Employee Performance & 0.251325 & 2.406071 & Accepted \\
$H_{6}$ & Labor Relations $\rightarrow$ Employee Performance & 0.342577 & 2.638642 & Accepted \\
& $\quad$ Indirect Relationship & & & \\
$H_{7}$ & Recruitment $\rightarrow$ Labor Relations & 0.594820 & 6.176724 & Accepted \\
$H_{8}$ & Recruitment $\rightarrow$ Employee Performance & 0.620351 & 7.616782 & Accepted \\
$H_{9}$ & Employee Retention $\rightarrow$ Employee Performance & 0.349052 & 3.126633 & Accepted \\
\hline \hline
\end{tabular}

From Table 4 hypothesis test results can be explained as follows: The coefficient of recruitment against the retention of employee of 0.61 with the T-statistic of 7.73 where those values are bigger than 1.96. These results indicate that there is a significant impact among recruitment against the employee retention, this means if the recruitment that is increasingly high, it will significantly increase the employee retention. Based on these results the $H_{1}$ is accepted. The coefficient of recruitment against the labor relations is 0.42 with T-statistic 2.84 where is bigger than 1.96 . These results indicate that there is significant impact between recruitment against the labor relations, this means if the recruitment that is increasingly high, it will significantly increase thelabor relations. 
Based on these results the $\mathrm{H}_{2}$ is accepted. The coefficient of employee retention against the labor relations of 0.285 with T-statistic 2.01 where is bigger than 1.96. These results indicate there is significant impact between the employee retention against labor relations, this means if the employee retention that is increasingly high, it will significantly increase the labor relations. Based on this result $H_{3}$ is accepted.

The coefficient of recruitment against the employee performance of 0.263 with Tstatistic 2.009 where is bigger than 1.96. These results indicate that there is a significant impact between the recruitment against employee performance, this means if the recruitment that is increasingly high, it will significantly increase the employee performance. Based on this result $\mathrm{H}_{3}$ is accepted. The coefficient of employee retention against the employee performance of 0.251 with a t-statistic 2.40 where is bigger than 1.96. These results indicate that there is a significant impact between the employee retention against employee performance, this means if the employee retention that is increasingly high, it will significantly increase the employee performance. Based on the results of these $H_{5}$ accepted. The coefficient of labor relations against the employee performance of 0.342 with T-statistic 2.64 where is bigger than 1.96. These results indicate that there is a significant impact on labor relations against employee performance, this means if the labor relations that is increasingly high, it will significantly increase the employee performance. Based on these results $\mathrm{H}_{6}$ accepted.

The coefficient of recruitment against the labor relations indirectly through the employee retention found of 0.595 with T-statistic 6.176 where is bigger than 1.96. These results indicate that there is a significant impact on recruitment against the labor relations through the employee retention, this means if the recruitment that is increasingly high, it will significantly increase the employee retention which in the end will also have an impact on the labor relations. Based on these results $H_{7}$ accepted. The coefficient of recruitment against the employee performance indirectly through the labor relations found of 0.620 with t-statistic 7.617 where is bigger than 1.96. These results indicate that there is a significant impact on recruitment against the employee performance through the labor relations, this means if the recruitment that is increasingly high, it will significantly increase the labor relations which in the end will also have an impact on the employee performance. Based on these results $H_{8}$ accepted. The coefficient of employee retention against the employee performance indirectly through the labor relations found of 0.349 with T-statistic 3.127 where is bigger than 1.96. These results indicate that there is a significant impact on employee retention against the employee performance through the labor relations, this means if the employee retention that is increasingly high, it will significantly increase the labor relations which in the end will also have an impact on the employee performance. Based on these results $H_{8}$ accepted.

\section{DISCUSSION}

Based on the results of the study, recruitment processes at each of the batik industry in Solo emphasized conformity engineering recruitment, significant impact towards the employee retention of the company due to its high recruitment then automatically also 
increases employee retention rate by these companies who want to maintain the tremendous potential employee. The statement is supported by the results of research conducted by Janjua and Gulzar (2014) stating the recruitment have significantly impact against the employee retention. It can be concluded that the results of such research in accordance with the first hypothesis testing. Other research by Karemu et al. (2014); Vispute, (2013); Zachariah and Roopa (2012); Mohammad (2015); Gberevbie (2010) also states recruitment had an impact toward the employee's retention.

The second hypothesis test showed that recruitment impact significant against the labor relations between employees on the batik industry in Solo. The appropriate recruitment and good will participate improve labor relations within the company and the statement is supported by the results of research that has been done by Tunggal and Setiawan (2015), who mention that new employee who do not comply with the Organization's objectives and ethos can damage working relationships and can inhibit the formation of working groups within the company.

In hypothesis testing, demonstrate the impact between the employee retention and the labor relations. A high employee's retention rate in the industry of batik Solo also affect working relationships between employees. A high employee's retention rate will improve the labor relations between employees, supported by the results of research conducted Sumarni (2011), that's a bad employee retention will increase the employee turnover. For an employee, a high turnover rate will affect employee morale, employee relations and work security or badly labor relations within the organization. Hypothesis test results of four indicates that company carried out recruitment process has a significant impact on the employee's performance. If the company is able to carry out recruitment, it will download the potential employee get and have good performance. It would be affected and motivating other employee. The statement is supported byte results of research conducted by Rafii and Andri (2015) which states the dominant va-riable recruitment is affected the employee's performance. Other research by Alqudah et al. (2014); Kepha et al. (2012); Tabiu and Nura (2013); Gberevbie (2010) also states recruitment had an impact toward the employee’s performance.

Test results prove the hypothesis five significant impact employee retention against employee performance. The company's efforts to retain employee's tremendous potential performance parts production to tackle and provide the best for his company. Supported by previous research suggesting that the higher employee then the higher em-ployee performance (Susilo, 2013). Other research by Hunjra et al. (2014); Nkosi (2015); Gberevbie (2010) also states employee retention had an impact toward the employee retention.

Test results show that there were six hypothetical impact significant between the labor relations between employees against employee's performance in the batik industry in Solo. Relations and communication that runs smoothly and is able to improve the employee's performance and reduce conflict between employees. The statement backed by research, according to Emmanuel, which concluded that communication is well entwined in the labor relations had an impact both for the 
employee performance where there is no need to spend time to argue over arguments for each employee (in Situngkir, 2013).

Test results showed that the seven hypotheses about recruitment impact significantly to labor relations through the employee retention. From the results of the study can be seen that with good recruitment process, then it will have an impact on the growing labor relations between employees through employee retention. In accordance with the results of previous research conducted Janjua and Gulzar (2014) stated that recruitment fair significantly affect employee retention. Besides the research results, Sumarni (2011) which states that with a good employee retention will improve the better employee relations. The eight hypothesis testing shows there is a significant impact among recruitment on the employee's performance through labor relations. The results of this study in accordance with the results of previous research conducted by the Tunggal and Setiawan (2015) stated there is a relationship between recruitment and labor relations. Recruitment can be badly labor relations within the organization. Recruitment requires time and costs are quite expensive, and so the decisions made must be appropriate. A new employee who does not comply with the organization's objectives and ethos can damage labor relations. Besides research results Situngkir (2013) which concluded that a relationship that is entwined in the team (group) a positive effect against the employee's performance. The last hypothesis testing proved there is impact employee retention against employee's performance through labor relations. The results of this study in accordance with the results of previous research conducted by Sumarni, (2011) stated there is a relationship between the employee retention with labor relations. A bad employee retention will increase employee turnover. For an employee, a high turnover rate will affect employee morale, employee relations and job security or badly labor relations within the organization. In addition, research results Situngkir (2013) which concluded that a relationship that is entwined in the team (group) a positive effect against the employee's performance. The results of the analysis over research conducted on the batik Solo show that proved the hypothesis suggests there is a connection between the variable recruitment, employee retention, the employee's performance and labor relations.

\section{CONCLUSION AND IMPLICATION}

Based on the results of the analysis that has been done, the managerial implications of this research for companies on the batik industry in Solo to make the employee of the company are mainly employee of part of the production to be able to further improve its performance in the company, which can be done by way of improving the recruitment process is good, the retention of good employee and keeping the labor relations between employee.

The increase in recruitment can be done by industrial firms at Solo batik by creating work environments that are not discriminatory, because now the results of the research shown, the batik industry employee in Solo still feel any discrimination in the work environment. Increased employee retention can be done by the company by creating comfort for employees, because employee still feels 
less happy while working. The improvement of the working relationship can be done by improving the quality of communication between employee, as many of them still feel less receive feedback from other employers.

Based on the research results and conclusions above, then there are several things that can be put forward as suggestions as follows:

1. Companies on the batik industry in Solo may consider to improve the suitability of the recruitment process by the company because of its links with the retention of employees, in accordance with the first hypothesis. According to the research, recruitment can be improved with due regard to the suitability of the recruitment pro-cess with what the company needs. The company will get employees who have the potential and the automatically companies will increase employee retention through potential employees.

2. In accordance with acceptance of the second hypothesis, the company may consider to improve recruitment because of its links with labor relations. When recruitment to consider is how the personality of the employee to avoid mistakes recruit people and adversely affected the labor relations between employees in the company.

3. Companies in the batik industry in Solo may consider increasing employee retention because it has a relationship with labor relations in accordance with the third hypothesis. Employee retention can be improved through career paths, rewards, compensation, etc., so that employees feel are needed in the company and show good ethics and ultimately will have an impact also on the labor relations between employees.

4. The acceptance the fourth hypothesis, the company may consider for pay attention to recruitment in the company because it has a relationship with the employee's performance. Recruitment is more considered in order of new employees are placed in divisions according to ability and skill of the person, so the employee can show a good performance at work.

5. Acceptance of the fifth hypothesis, the company may consider to improve the retention of employees in the company in the batik industry in Solo because it proved to have a relationship with the employee's performance. Employee retention can be done by giving convenience to employees at work so can be loyal to the company, shows the best performance at work, which of course it is very advantageous for the company.

6. Companies in the batik industry in Solo may consider to improve working relationships between employees because it proved to have a relationship with the employee's performance, according to the sixth hypothesis. Labor relations between employees can be improved one of them through joint events outside the company or outside the affairs of between employees work so get to know each other, so employees are happy to work either individually or in teams and showed a good performance. 
7. A company in the batik industry in Solo may consider to improve working relationships between employees through the implementation of recruitment and retention of employees. Labor relations can be improved either by increasing the productivity, the company ensures that its employees in the work have the same goal, from the tasks and responsibilities. Companies can reevaluate the recruitment process that has been applied and the retention of employees has been effective or not.

8. Companies in the batik industry in Solo may consider to improve employee performance through the implementation of recruitment and labor relations. Employee performance can be improved by the implementation of a good and correct recruitment, training, good working conditions, awards, and others.

9. Companies in the batik industry in Solo may consider to improve employee performance through employee retention and labor relations. Employee performance through retention can be improved by an increase a sense of fun and the convenience while working in the company. If employees are glad to be in the company, em-ployees are less likely to intend to leave the company, so employees will behave obey the existing regulations and willing to work in groups, that will automatically improve working relationships between employees.

10. The results of the descriptive analysis about the education level that employees most educated junior high school below, it shows that to be batik craftsmen none specific requirements about the educational background and anyone can be a batik craftsman, enough an interest in art of batik. The company can establish batik academy to regenerate and prepare professional staff among the young generation were ready to plunge into the industrial sector, which is also for the regeneration of batik which is currently on average already old.

\section{REFERENCES}

Alqudah, M. H. A., Osman, A., \& Alqudah, H. E. M. (2014). The Effect of Human Resources Management Practices on Employee Performance. International Journal of Scientific \& Technology Research, 3(9), 129-134.

Ernawati, N., \& Ambarini. (2010). Influence Employment Relations and Working Environment on Employee Performance with Work Motivation as Moderating Variables. Journal of Economics and Entrepreneurship, 10(2), 109-118.

Gberevbie, D. E. (2010). Strategies for Employee Recruitment, Retention and Performance: Dimension of The Federal Civil Service of Nigeria. African Journal of Business Management, 4(8), 1447-1456.

Ghozali, I. (2014). Structural Equation Modeling: Alternative Methods with Partial Least Square (PLS). Semarang: Diponegoro University.

Gomes, F. C. (2003). Human Resource Management. Yogyakarta: ANDI. 
Hunjra, A. I., Raza, H., \& Munir, I. U. (2014). The Role of Employee Retention and Employee Productivity on the Performance of Oil \& Gas Sector of Pakistan. International Journal of Economics and Empirical Research, 2(11), 449-453. Janjua, B. H., \& Gulzar, A. (2014). The Impact of Human Resource Practices on Employee Commitment and Employee Retention in Telecom Sector of Pakistan: Exploring the Mediating Role of Employee Loyalty. IOSR Journal of Business and Management, 16(1), 76-81.

Karemu, G., Kahara, G., \& Josee, V. (2014). An Analysis of the Effect of Employee Recruitment Strategies on Employee Retention at Equity Bank, Kenya. European Journal of Business and Management, 6(17), 90-97.

Kepha, O., Mukulu, E., \& Waititu, G. A. (2012). The Influence of Recruitment and Selection on The Performance of Employees in Research Institutes in Kenya. International Journal of Science and Research, 3(5), 132-138.

Kristanto, H. (2015). Organizational Justice, Organizational Commitment and Employee Performance. Journal of Management and Entrepreneurship, 17(1), 86-98.

Maina, B. W. (2014). Effect of Human Resource Management Practices on Employees Retention in Institutions of Higher Learning in Kenya: A Case Study of Kenyatta University. The Strategic of Business \& Change Journal of Manage-ment, 1(2), 258-277.

Matalia (2012). Influence Leadership and Labour Relations on Career Development and Employees Job Satisfaction in the Secretariat of the Office of the Provincial Government of Bali. Journal of Management, Business Strategy and Entrepreneurship, 6(2), 185-194.

Mohammad, A. Q. (2015). Employee Recruitment, Selection and Retention in Saudi Arabian Family Owned Small and Medium Scale Enterprises (SME'S). Kuwait Chapter of Arabian Journal of Business and Management Review, 4(6), 30-45. Nkosi, S. M. (2015). Effects of Training on Employee Commitment, Retention and Performance: A Case Study of a Local Municipality in South Africa. European Journal of Business and Management, 7(15), 104-108.

Pambagio, N. S., Utami, H. N., \& Gunawan, E. (2013). Influence of Process Recruitment, Selection Process and Competence of Employee on Employee Performance (Studies on the Employees Division of Administration and Finance PG Kebon Agung Malang). Journal of Business Administration, 4(1), 1-7.

Patimah, S. (2015). The Influence of Recruitment and Selection on The Performance of State Elementary School Principals Bandar Lampung. Scientific Journals Peuradeun - International Multidisciplinary Journal, 3(1), 165-190.

Rafii, M., \& Andri, S. (2015). The Influence of Employee Recruitment and Placement on Employee Performance on PT. Bank Riaukepri Pekanbaru. Online Journal of Indonesia Faculty of Social and Political Sciences, 2(1), 1-12.

Rivai, V., \& Basri, A. F. (2005). Performance Appraisal: Right System for Assessing Employee Performance and Increase Company Competitiveness. Jakarta: PT. Raja Grafindo Persada. 
Situngkir, S. A. (2013). The Influence of Financial Compensation, Labour Relations and Working Physical Environment on Employee Performance in Regional Company Parking Denpasar City. E-Journal of Management, University of Udayana, 2(8), 1019-1035.

Sumarni, M. (2011). The Influence of Employee Retention on Turnover Intention and Employee Performance. AKMENIKA UPY, 8, 20-47.

Sunyoto, D. (2012). Human Resource Mangement. Yogyakarta: CAPS (Center for Academic Publishing Service).

Susilo, A. (2013). The Influence of Employee Retention and Customer Satisfaction to Performance. Studia Journal of Accounting and Business, 1(3), 247-262.

Tabiu, A., \& Nura, A. A. (2013). Assessing The Effects of Human Resource Management (HRM) Practices on Employee Job Performance: A Study of Usmanu Danfodiyo University Sokoto. Journal of Business Studies Quarterly, $5(2), 247-259$.

Tunggal, A. C., \& Setiawan, R. (2015). Descriptive Study of Recruitment and Selection at PT. Multi Artistikacithra. AGORA, 3(1), 647-650.

Vispute, S. (2013). Recruitment Strategy and Employee Retention in Indian Banking and Insurance Sector. International Journal of Arts \& Sciences, 6(2), 743-756.

Werner, S., Schuler, R. S., \& Jackson, S. E. (2012). Human Resource Management. Canada: South-Western Cencage Learning.

Zachariah, M., \& Roopa, T. N. (2012). A Study on Employee Retention Factors Influencing It Professionals of Indian It Companies and Multinational Companies in India. Interdisciplinary Journal of Contemporary Research in Business, 4(7), 449-466. 